\title{
Phylogeny, historical biogeography and the evolution of migration in accipitrid birds of prey (Aves: Accipitriformes)
}

\author{
JENÖ NAGY ${ }^{1} \&$ JÁCINT TÖKÖLYI ${ }^{*}$
}

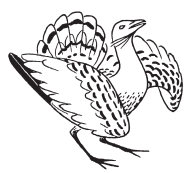

Jenő Nagy \& Jácint Tökölyi 2014. Phylogeny, historical biogeography and the evolution of migration in accipitrid birds of prey (Aves: Accipitriformes). - Ornis Hungarica 22(1): 15-35.

\section{have originated in par large-scale seasonal movements that characterize temperate migration systems appear to}

Abstract Migration plays a fundamental part in the life of most temperate bird species. The regular, large-scale seasonal movements that characterize temperate migration systems appear to fluenced by a number of ecological factors, such as the ability to survive harsh winters. Hence, understanding the origins and evolution of migration requires integration of the biogeographic history and ecology of birds in a phylogenetic context. We used molecular dating and ancestral state reconstruction to infer the origins and evolutionary changes in migratory behavior and ancestral area reconstruction to investigate historical patterns of range evolution in accipitrid birds of prey (Accipitriformes). Migration evolved multiple times in birds of prey, the earliest of which occurred in true hawks (Accipitrinae), during the middle Miocene period, according to our analyses. In most cases, a tropical ancestral distribution was inferred for the non-migratory ancestors of migratory lineages. Results from directional evolutionary tests indicate that migration evolved in the tropics and then increased the rate of colonization of temperate habitats, suggesting that temperate species might be descendants of tropical ones that dispersed into these seasonal habitats. Finally, we found that diet generalization predicts migratoriness in this group.

Keywords: ancestral area reconstruction, annual cycle, comparative, diet specialization, diurnal birds of prey, molecular dating, seasonality

Összefoglalás A legtöbb mérsékelt övi madárfaj életciklusában alapvető szerepet tölt be a vonulás. A rendszeres, nagy kiterjedésủ mozgások, melyek a mérsékelt övi vonulási rendszereket jellemzik, egyes feltételezések szerint a trópusi fajok poszt-glaciális, északi irányú terjeszkedésével párhuzamosan jelentek meg. Ezen felül a vonulás előfordulását számos ökológiai tényező is befolyásolhatja, mint például a környezet szezonalitásának mértéke vagy a téli túlélést befolyásoló tényezők. A vonulás eredete és evolúciója ezért csak úgy érthető meg, ha a madarak biogeográfiai történetiségét és ökológiáját filogenetikai kontextusban tanulmányozzuk. Jelen vizsgálatban a vágómadár-alakúak (Accipitriformes) vonulásának evolúcióját elemeztük komparatív módszerekkel. Első lépésben létrehoztunk egy fosszilis adatok alapján datált molekuláris törzsfát, amelyen jellegrekonstrukciót végeztünk és rekonstruáltuk a fajok ősi elterjedési területét. Az elemzéseink alapján a vonulás többször alakult ki a ragadozók esetében, legkorábban a héjaformákon (Accipitrinae) belül, vélhetően a Miocén közepén. A legtöbb esetben a vonuló leszármazási vonalak nem vonuló őseinél trópusi elterjedésre következtethetünk. A direkcionális evolúciós teszt alapján a vonulás a trópusokon jelent meg és megnövelte a mérsékelt égöv kolonizációjának rátáját. Eszerint tehát a mérsékelt övi ragadozómadár fajok vonuló trópusi fajok leszármazottainak tekinthetők, melyek az erősen szezonális, északi élőhelyek irányába terjeszkedtek. Végezetül negatív kapcsolatot találtunk a vonulás megjelenése és a táplálékspecializáció mértéke között.

Kulcsszavak: éves ciklus, jellegrekonstrukció, komparatív, molekuláris datálás, nappali ragadozómadarak, szezonalitás, táplálékspecializáció

\footnotetext{
${ }^{1}$ MTA-ELTE-MTM Ecology Research Group, 1117 Budapest, Pázmány Péter sétány 1/C, Hungary, e-mail: jenonagy.off@gmail.com

${ }^{2}$ MTA-DE "Lendület" Behavioural Ecology Research Group, Department of Evolutionary Zoology and Human Biology, University of Debrecen, 4032 Debrecen, Egyetem tér 1., Hungary, jtokolyi@vocs.unideb.hu

*corresponding author
} 


\section{Introduction}

Birds originated, according to our current knowledge of the fossil record, about 150200 million years ago during the geological era of Jurassic (Padian \& Chiappe 1998). The appearance of powered flight, probably in combination with several other avian features such as warm-bloodedness and the presence of extensive parental care has fuelled the diversification of this group of vertebrates, which seems to have accelerated around, or shortly after the CretaceousPaleogene boundary (Ericson et al. 2006, Brown et al. 2008, Jetz et al. 2012).

The widespread occurrence of birds is greatly facilitated by their excellent dispersal capabilities. This is perhaps most clearly seen in migratory birds, which can travel thousands of kilometres on continental scale within a single year. Migration is a characteristic feature of birds that is extremely common especially in species inhabiting the Northern Hemisphere temperate zone and the Arctic, but it also occurs, although in less extreme forms, in other regions of the globe in the form of intratropical migration systems (Alerstam 1993, Berthold 2001, Newton 2008).

Migration itself profoundly influences the distribution, ecology and diversification of birds (Newton 2008), hence it is not surprising that a great deal of information has accumulated on its internal, proximate determinants and its phenology ever since Hans Christian Mortensen started ringing birds at the very end of the $19^{\text {th }}$ century. These studies revealed that the migratory phenotype is determined by a set of complex and tightly regulated mechanisms (Gwinner 1990), which includes, among others (1) sensory elements underlying orientation and navigation, (2) mechanisms responsible for the regulation of migratory restlessness ('zugunruhe') during the annual cycle and (3) a range of physiological adaptations that cover the metabolic requirements of long-distance flights during migration. Understanding how such a complex phenotype could have evolved is a major challenge in ornithology.

While a wealth of information has accumulated on the details of the process of migration, comparatively little is known about how migration originated and evolved in birds. This is not surprising, since behavioral traits, such as the migratory habits of a species do not fossilize and hence our current ideas of it are strictly inferred from phylogenetic or biogeographic studies. Current theories of the evolution of migration can be divided into two groups (Rappole \& Jones 2002, Bruderer \& Salewski 2008). The 'tropical origin' hypothesis proposes that migratory birds derive from species inhabiting regions where environmental factors were constant during the year, so there was no need for migration. These species could have colonized more seasonal, northern habitats, which, during the summer months provided appropriate conditions for reproduction. However, during winter food availability decreased, hence these birds were forced to return to southern latitudes (Rappole \& Jones 2002, Bruderer $\&$ Salewski 2008). Cox (1985) developed a stepping-stone model of this hypothesis. According to this model, resource-limitation due to competition for food forced certain tropical resident species to expand their range to the subtropics. These birds continued to return to the tropics during the winter, resulting in the formation of partial migrant species. These partial migrants then continued to spread to higher latitudes where they were able to breed successfully while still returning to the original area in the winter 
(Stiles 1980, Cox 1985). Thus, this hypothesis predicts that migratory species evolved from tropical ancestors.

Several lines of evidence support the tropical origin of long-distance migrants. Joseph et al. (1999), in a study of waders, analyzed the evolution of breeding and wintering distribution of 16 species from the genus Charadrius using phylogenetic methods. By reconstructing the hypothesized distribution of the ancestors of these birds, they showed that species that are migratory today derive from ancestors whose breeding and non-breeding ranges were located in the tropical zone. Another similar study investigated the evolution of migration in $\mathrm{Ca}$ tharus thrushes (Outlaw et al. 2003). This study showed that North American (migratory) thrushes are sister to tropical species, and the ancestral area for the whole lineage was inferred to be in the Neotropics, providing further support for the "tropical origin' hypothesis. This pattern is not restricted to interspecific comparisons but is also seen among populations differing in migratory status. For instance, in a study of North American Chipping Sparrows (Spizaella passerina), Milá et al. (2006) have shown that the northern, long-distance migrant populations descend from non-migratory Mexican populations, which colonized North America after the last glacial maximum 18000 years ago. Thus, long-distance migration and colonization of temperate regions in this species developed in tandem.

Other hypotheses on the origin of migration emphasize the importance of changes on the breeding territories of birds with a northern distribution ('northern origin' hypothesis) (Bell 2000, 2005, Bruderer \& Salewski 2008). According to these suppositions, climatic or other ecological changes (e.g. global cooling) could have led to the evolution of migration by forcing non-migratory temperate and arctic species to leave there home ranges during the winter (Bell 2000, 2005), resulting in migratory strategies which allowed the survival of populations in a strongly seasonal milieu (Bell 2000, 2005). Thus, this hypothesis predicts that migration evolved from temperate resident species, a prediction that has received relatively low support to date. It is clear, however, that migration can evolve without the expansion of the breeding ranges, as examplified by the large number of intra-tropical migrants (e.g. Boyle \& Conway 2007, Boyle et al. 2011). Comparative studies of the occurrence of migration among some of these tropical taxa, such as the passerine group Tyranni revealed that a number of ecological traits, specifically diet and habitat, predict whether a species is migratory or not in the tropics (Boyle \& Conway 2007, Boyle et al. 2011). Thus, year-round variation and predictability of food sources (Boyle \& Conway 2007, Boyle et al. 2011), as well as the ability to exploit these sources (Bell 2011, Boyle et al. 2011) appears to predispose some avian taxa for migration.

As the examples above suggest, the evolution of migration in birds is a complex problem that requires an integrative approach combining aspects of the historical biogeography (range expansions), ecology (habitat, food availability) and behavioral ecology (diet specialization) of birds. Yet, phylogenetic studies often target only one of these aspects, while ignoring others. Here, we describe an attempt for such an integrative approach using accipitrid birds of prey (Accipitriformes) as a model group. This taxon is ideal for our purpose because it includes both tropical and temperate species and there is wide variation in migratory behavior, habitat and diet within the group (Ferguson-Lees 
\& Christie 2001). Specifically, we investigate the following: (1) the phylogeny and historical biogeography of diurnal birds of prey; (2) the evolutionary origins of migration in raptors in a phylogenetic context and (3) the ecological and behavioral traits that are associated with migratoriness in this group. The traits we investigate are body mass, diet and habitat. Body mass influences nearly all aspects of birds' life and could be a crucial factor determining which species can survive periods of food shortage and/or cold wheather (e.g. Newton 2008). Therefore, we hypothesize that larger birds are more likely to become residents (or vice versa: residents might be selected to become larger) (Tökölyi \& Barta 2011). Diet can be important for two reasons: first, raptors feeding on warm-blooded prey or carcass are more likely to survive the winter at temperate latitudes and hence be non-migratory. Second, species with a generalist diet should be more likely to subsist during periods of resource shortage by finding alternative food sources, hence we predict that food generalists are more fre- quent in migrants. Lastly, habitat type was hypothesized to be important in the evolution of tropical-temperate migration systems because it could have determined the availability of suitable corridors for tropical-temperate dispersal routes (Rappole \& Jones 2002). Rappole and Jones (2002) noted that the majority of long-distance migrants in the Nearctic spend the winter in forests, whereas almost none of the Palearctic/Asian migrants do so. They proposed that the lack of forested habitats in North Africa could have acted as a dispersal barrier, effectively filtering range expansions from south. Therefore, we tested whether habitat type is associated with migratoriness in birds of prey.

\section{Methods}

\section{Phylogenetic reconstruction and molecular dating}

The list of genes used to reconstruct the molecular phylogeny of birds of prey for

\begin{tabular}{|l|c|c|c|}
\hline Gene (Abbreviation) & No species & No. bp & Model \\
\hline 12S ribosomal RNA (12S) & 74 & 900 & TIM2+I+G \\
\hline 16S ribosomal RNA (16S) & 53 & 1527 & GTR+I+G \\
\hline ATP synthase F0 subunit 6 (ATP6) & 56 & 684 & TrN+I+G \\
\hline ATP synthase F0 subunit 8 (ATP8) & 56 & 168 & TrN+I+G \\
\hline$\beta$-fibronigen intron 7 (BFI7) & 69 & 922 & TVM+G \\
\hline Cytochrome c oxidase subunit 1 (COX1) & 86 & 1551 & TIM2+I+G \\
\hline Cytochrome b (CYTB) & 164 & 1146 & TIM3+I+G \\
\hline NADH-ubiquinone oxidoreductase subunit 2 (ND2) & 151 & 1047 & GTR+I+G \\
\hline NADH-ubiquinone oxidoreductase subunit 2 (ND6) & 66 & 525 & GTR+I+G \\
\hline Recombinase activating gene 1 (RAG1) & 87 & 2872 & GTR+I+G \\
\hline
\end{tabular}

Table 1. Gene sequences used to reconstruct the phylogeny of Accipitriformes, their availability, length and the most appropriate evolutionary model of sequence evolution applying to them, as evaluated by jModelTest

1. táblázat A vágómadár-alakúak törzsfa-rekonstrukciójához használt génszekvenciák neve, elérhetősége (fajok száma), hossza és a jModelTest által meghatározott legmegfelelőbb evolúciós modell 
which genetic data is available is shown in Table 1. All sequences were retrieved from GenBank (http://ncbi.nlm.nih.gov/). Sequences were aligned using MAFFT-LINSI (Katoh et al. 2005) with default parameters and alignments were visually checked. Two alignments (12S and 16S) contained multiple indels and were run through Gblocks (Castresana 2000) to remove poorly aligned positions. Sequence management was done in the R statistical environment ( $\mathrm{R}$ Development Core Team 2012) using functions from libraries ape (Paradis et al. 2004) and seqinr (Charif \& Lobry 2007).

Alignments were concatenated and species with few data ( $<500$ nucleotides) were removed. The median sequence length for the remaining 180 species was 1038 base pairs (range 519-2872) (Table 1). This taxonomic sample represents approximately $70 \%$ of extant species.

The resulting sparse supermatrix was used to reconstruct the phylogenetic relationships of the 180 species. First, RAxML (Stamatakis 2006) was used to obtain a starting tree for phylogeny estimation. We used a rapid bootstrap analysis with 100 bootstrap replicates followed by a search for the best-scoring maximum likelihood tree, using the GTR $+\mathrm{I}+\mathrm{G}$ model of evolution. The Secretary Bird Sagittarius serpentinus (Sagittariidae) was used as an outgroup in this process; the sister relationship between Sagittariidae and the rest of the Accipitriformes (Pandionidae and Accipitridae) is well supported from molecular phylogenetic studies (e.g. Ericson et al. 2006, Brown et al. 2008, Hackett et al. 2008).

Next, the best-scoring tree obtained from this analysis was used as a starting tree in a Bayesian MCMC analysis (implemented in BEAST; Drummond \& Rambaut 2007) to simultaneously reconstruct the phyloge- ny and divergence times of birds of prey. The ten gene segments were partitioned separately and each gene segment was assigned its own best-fit evolutionary model, as evaluated by Akaike Information Criterion (AIC) in the software jModelTest 2 (Guindon \& Gascuel 2003, Darriba et al. 2012) (Table 1).

Molecular dating was done using an uncorrelated relaxed molecular clocks approach, which takes into account variation in the rate of molecular evolution among lineages (Drummond et al. 2006). Three fossil constraints were used to date the phylogenetic tree (following do Amaral et al. 2009 and references therein): (1) the minimum age of divergence between Pandionidae and Accipitridae was set to 37 Mya, based on the oldest known fossil belonging to Pandionidae (Harrison \& Walker 1976); (2) the maximum age of divergence for $\mathrm{Bu}$ teo galapagoensis was set to 4 Mya and (3) the maximum age of divergence for $B$. solitarius was set to 5.1 Mya. B. galapagoensis and B. solitarius are both island species (restricted to the Galapagos Islands and Hawaii, respectively) and the latter two age constraints are based on the assumption that these species cannot be older then the islands which they inhabit (do Amaral et al. 2009). Two independent BEAST runs were performed, each allowed to run for 50000000 generations with a thinning interval of 5000 generations. Convergence was evaluated by checking effective sample size (ESS) of parameters in Tracer (Rambaut \& Drummond 2012). All parameters had ESS values $>100$ and most were $>>200$. The two runs were combined (after removing $10 \%$ burnin) and resampled at intervals of 10000 generations to yield 9000 trees that represents a sample of the posterior distribution of phylogenetic trees. A maxi- 
mum clade credibility tree was generated from this sample in TreeAnnotator (Rambaut \& Drummond 2012).

To visualize diversification rate through time, we created a lineages-through-time plot for 100 trees selected randomly from the posterior sample and the maximum clade credibility tree.

\section{Ancestral area reconstruction}

We collected breeding season distribution data on 180 species from Ferguson-Lees and Christie (2001). Species were scored as present/absent in the following biogeographical realms: Nearctic, Palearctic, Neotropical, Afrotropical, Malagasy, Indomalayan, Australasian. The delimitation of these realms is based on Ferguson-Lees and Christie (2001).

We inferred ancestral ranges based on this distribution data by employing probabilistic historical biogeography methods using the BioGeoBEARS R package (Matzke 2013). These methods model geographic range evolution by assuming different forms of anagenetic and cladogenetic changes in geographic distribution during speciation events: dispersal, extinction, vicariance, sympatric speciation and founder-event speciation. We evaluated which of the traditionally used historical biogeographic models best fits range evolution in birds of prey by calculating and comparing six models using Akaike Information Criterion. These models are the Dispersal-Vicariance (DIVA) model (Ronquist 1997), the Dispersal-Extinction-Cladogenesis (DEC) model (Ree et al. 2005, Ree \& Smith 2008) and the BayArea model (Landis et al. 2013), together with the combination of these three with founder-event speciation. The three baseline models all assume dispersal, extinction, sympatric speciation and vicariance as possible range evolution mechanisms but differ in the way they treat sympatric and vicariant speciation events: the DIVA model allows narrow-scale sympatry but both narrow and widespread vicariance. The DEC model assumes narrow-scale and subset sympatry, but only narrow-scale vicariance whereas BayArea assumes narrow-scale and widescale sympatry to occur (Matzke 2013). We used the best fit of these models to estimate the most likely ancient distributions at each node (ancestor state) of the phylogeny. The method also gives a relative probability, ranging from 0 to 1 , which gives the probability that the node was in the given state. The higher this value, the higher is our confidence in the actual reconstuction is correct and uncertainity in the ancestral range reconstruction is low. These analyzes were done using the maximum clade credibility tree.

\section{Life history data}

All data, with the exception of body mass information, were collected from Ferguson-Lees and Christie (2001), complemented from the Global Raptor Information Network (2013), if necessary. Migratory behavior was categorized based on previous phylogenetic studies (e.g. Kondo \& Omland 2007, do Amaral et al. 2009) as: (1) non-migratory (no seasonal movements present), (2) partially migratory (part of the populations, or part of the individuals within the species perform regular seasonal movements) and (3) completely migratory (all populations and individuals migratory). We used this variable to infer rates of evolution to and from complete migration (see below). However, the number of completely migratory species was relatively low in our 
sample $(\mathrm{N}=13)$, therefore, migration was binarized in all other analyzes as either migratory or non-migratory.

Information on body mass was obtained from Dunning (2008), and in a few cases from Ferguson-Lees and Christie (2001). We used the average of male and female body masses (log-transformed) when they were available; however, in 8 cases data on male or female body mass was available only. For 29 species no reliable body mass data could be found.

Diet (winter diet) was categorized following Roulin and Wink (2004). These authors assigned a relative importance value ranging from 1 to 9 to each of nine food categories (live birds, mammals, reptiles, fish, amphibians, crustaceans, insects, worms and carrion) based on descriptions of individual species' diet in Ferguson-Lees and Christie (2001). Food types that do not appear in the diet of a species received a score of 9 , whereas the most important food type received a score of 1 . From these values, we calculated reliance on warm-blooded prey and carrion as the minimum of the importance scores received for bird or mammal prey or carrion. Diet specificity was estimated by counting the number of food types in the diet of a given species that received a score $<9$.

Finally we classified habitat type as open or closed based on descriptions in Ferguson-Lees and Christie (2001).

\section{Comparative analyzes}

We performed Bayesian ancestral state reconstruction in BEAST (Drummond \& Rambaut 2007) to infer the migratory behavior at ancestral nodes in the phylogeny of birds of prey. Migratory behavior was recoded as a binary variable for this analysis (as either migratory or non-migratory, thus complete and partial migrants were collated). Bayesian ancestral state reconstruction takes into account phylogenetic uncertainty and calculates the probability that a given node was migratory or non-migratory, based on the trait values of its ancestor and descendants. By taking into account uncertainity in phylogenetic reconstruction, this method is substantially better than parsimony-based reconstructions, whose outcome is conditional on a single (possibly erroneous) topology. In addition, Bayesian ancestral state reconstruction also takes into account differences in branch lengths, which makes them more realistic than parsimony-based methods.

Next, we investigated how changes in migratory behavior occurred on the phylogeny by estimating transition rates between the three levels of migratory behavior (i.e. the rate of transition from migratory to partial or complete migrant and vice versa, and the rate of transition from partial to complete migrant and vice versa). This analysis was done using the MultiState module of BayesTraits 1.0 (Pagel et al. 2004).

We determined whether body size (logtransformed), habitat type, diet breadth, reliance on warm-blooded prey and geographical location (Old vs. New World) affects migratory behavior by constructing a multivariate phylogenetic generalized linear mixed models as implemented in the MCMCglmm package in R (Hadfield \& Nakagawa 2010), with these traits as dependent variables. We also included the interaction between habitat and geographical occurrence to model the differences in habitat use among Old World and New World migrants.

Lastly, we tested the correlated evolution among migration and explanatory variables found to be significant in the multiva- 
riate analyses using the Discrete module of BayesTraits 1.0 (Pagel \& Meade 2006). This method evaluates transition rates among pairs of binary traits on a phylogeny revealing details of correlated evolution among traits. For example, when analyzing the correlated evolution between migration and diet specificity one can ask whether migration is more likely evolve in generalist (or specialist) lineages or vice versa: does a generalist (or specialist) diet evolve more likely in migrants? Since this analysis can handle only binary traits we dichotomized diet specificity as specialist ( $<5$ food types consumed) or generalist (at least 5 food types consumed).

\section{Results}

\section{Phylogeny and diversification of Accipitriformes}

Figure 1 shows the relationship between major lineages of raptors. Our analysis recovered the relationships among major lineages of birds of prey described in previous molecular phylogenetic studies (Wink \& Sauer-Gürth 2004, Lerner \& Mindell 2005, Griffiths et al. 2007). Crown group Accipitriformes (i.e. the split between $\mathrm{Sa}$ gittarius and the rest of the species) is inferred to have originated $\sim 4$ million years ago $(95 \%$ highest posterior density interval: $56.4-37.4$ ), during the Eocene period. The

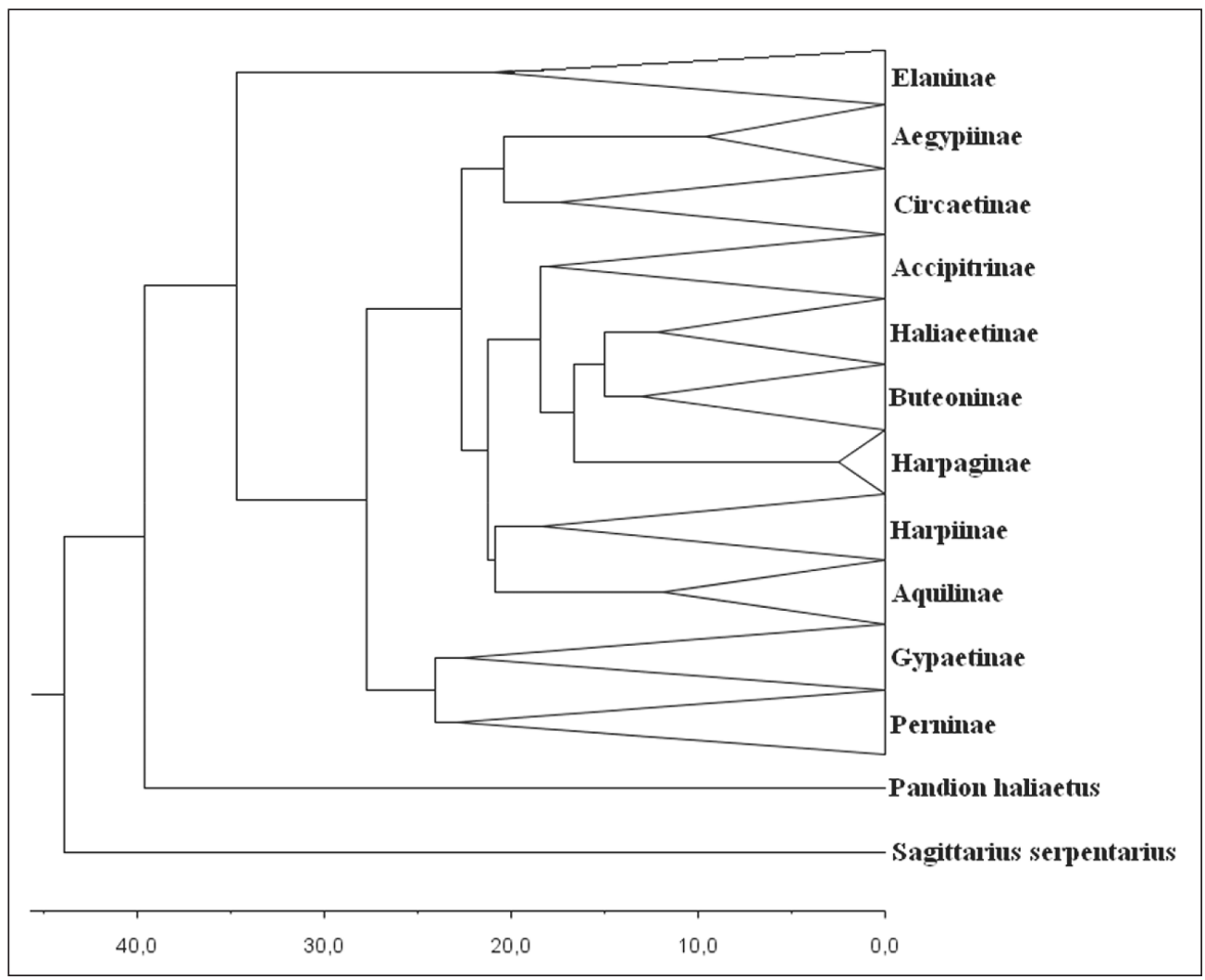

Figure 1. Simplified phylogeny showing major sublineages of Accipitriformes

1. ábra Egyszerűsített törzsfa a vágómadár-alakúak főbb csoportjainak filogenetikai viszonyairól 


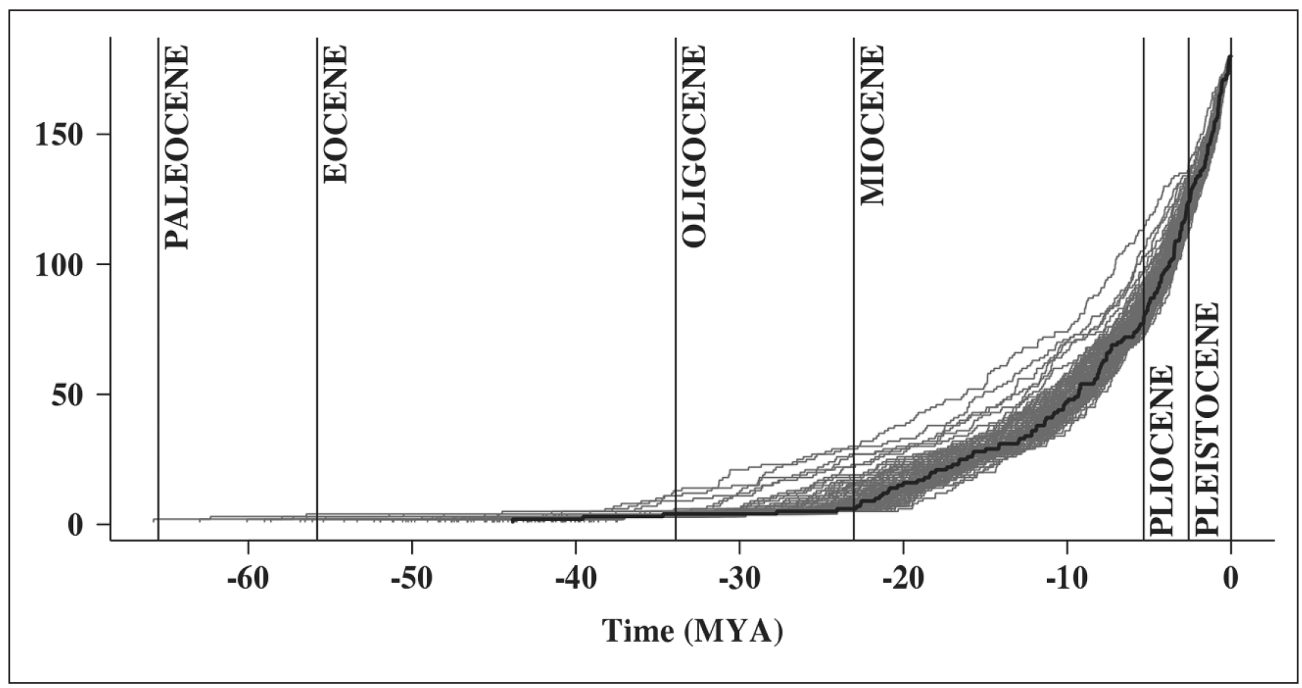

Figure 2. Lineages-through-time plot showing the pattern of diversification and accumulation of raptor species through time as reconstructed by our multi-gene relaxed molecular dating analysis. Grey lines show random trees $(\mathrm{N}=100)$ from the posterior sample of dated ultrametric trees obtained from BEAST; the black line denotes the maximum clade credibility tree

2.ábra A vágómadár-alakúak diverzifikációja a molekuláris datálás alapján. A szürke vonalak a törzsfa-rekonstrukció során létrehozott poszterior mintából 100 véletlenszerűen kiválasztott ultrametrikus fa, a fekete vonal pedig az összegzett mintából számolt ultrametrikus fa ágainak számát mutatja az idő függvényében

split between Pandion and the rest of Accipitriformes occurred $\sim 39.5$ million years ago (95\% highest posterior density interval: 49.5-37). The two earliest branchings within Accipitridae resulted in the appearance of elanid kites (Elaninae) $\sim 34.7$ million years ago $(95 \%$ highest posterior density interval: 44.3-29.4) and the group containing Gypaetinae and Perninae ( $\sim 27.7$ million years ago; $95 \%$ highest posterior density interval: 35.3-23.2). Then, around the start of the Miocene period the diversification of raptors accelerated and continued at a high rate until recent times (Figure 2).

\section{Ancestral area reconstruction}

The best model describing range evolution in birds of prey was the DEC model containing founder-event speciation. Based on this model, a southern origin was inferred for all raptor subfamilies. These analyses suggest that Accipitrinae, Aegypiinae and Gypaetinae have an Afrotropical origin, whereas Elaninae and Perninae derive from the Neotropics. Buteoninae and Harpiinae had a joint Afrotropical/Neotropical distribution according to our reconstruction, whereas Aquilinae have an Afrotropical/ Neotropical and Indomalayan origin, although we note that the accuracy of these reconstructions is quite low $(<0.3)$ (Table 2). Circeatinae were assigned an Indomalayan origin with relatively high probability (0.87) (Table 2). Lastly, the most likely ancestral distribution of Haliaeetinae was Australasia. 


\begin{tabular}{|c|c|c|c|c|}
\hline Subfamily & Genera & $\begin{array}{c}\text { Node age } \\
\text { (Mya; } 95 \% \\
\text { HPD interval) }\end{array}$ & $\begin{array}{l}\text { Ancestral } \\
\text { distribution }\end{array}$ & Prob. \\
\hline Accipitrinae & $\begin{array}{l}\text { Accipiter, Circus, Kaupifalco, Melierax, } \\
\text { Urotriorchis }\end{array}$ & $15.1 ; 23.0$ & At & 0.79 \\
\hline Aegypiinae & $\begin{array}{l}\text { Aegypius, Gyps, Necrosyrtes, Sarcogyps, } \\
\text { Torgos, Trigonoceps }\end{array}$ & $7.4 ; 12.6$ & At & 0.78 \\
\hline Aquilinae & $\begin{array}{l}\text { Aquila, Hieraaetus, Ictinaetus, } \\
\text { Lophaetus, Nisaetus, Oroaetus, } \\
\text { Polemaetus, Spizaetus, Spizastur, } \\
\text { Stephanoaetus }\end{array}$ & $9.8 ; 15.4$ & NtAtlm & 0.26 \\
\hline Buteoninae & $\begin{array}{l}\text { Busarellus, Butastur, Buteo, Buteogallus, } \\
\text { Geranoaetus, Geranospiza, } \\
\text { Harpyhaliaetus, Ictinia, Leucopternis, } \\
\text { Parabuteo, Rostrhamus }\end{array}$ & $10.3 ; 16.7$ & NtAt & 0.24 \\
\hline Circaetinae & $\begin{array}{l}\text { Circaetus, Dryotriorchis, Pithecophaga, } \\
\text { Spilornis, Terathopius }\end{array}$ & $13.8 ; 22.5$ & Im & 0.87 \\
\hline Elaninae & Elanus, Gampsonyx & $14.4 ; 29.4$ & $\mathrm{Nt}$ & 0.15 \\
\hline Gypaetinae & $\begin{array}{l}\text { Gypaetus, Gypohierax, Neophron, } \\
\text { Polyboroides }\end{array}$ & $18.5 ; 29.0$ & At & 0.99 \\
\hline Haliaeetinae & $\begin{array}{l}\text { Haliaeetus, Haliastur, Ichthyophaga, } \\
\text { Milvus }\end{array}$ & $9.8 ; 15.7$ & $\mathrm{Au}$ & 0.30 \\
\hline Harpiinae & $\begin{array}{l}\text { Harpia, Harpyopsis, Macheiramphus, } \\
\text { Morphnus }\end{array}$ & $13.6 ; 24.4$ & NtAt & 0,20 \\
\hline Perninae & $\begin{array}{l}\text { Aviceda, Chondrohierax, Elanoides, } \\
\text { Eutriorchis, Hamirostra, Leptodon, } \\
\text { Lophoictinia, Pernis }\end{array}$ & $18.7 ; 29.4$ & $\mathrm{Nt}$ & 0.15 \\
\hline
\end{tabular}

Table 2. Geographic origin of major sublineages of Accipitriformes as inferred from the ancestral area reconstruction following a dispersal-extinction-cladogenesis-founder-event speciation $(\mathrm{DEC}+\mathrm{J})$ model of geographic area evolution. This table lists the major subfamilies of Accipitriformes, the genera they contain, the inferred age of these groups (age of the crown group, i.e. the most recent common ancestor of all extant species), shown as $95 \%$ highest posterior density interval (HPD) and the most likely ancestral area inferred for the crown group, along with the probability that the node was in the given state. Geographic distribution is abbreviated as: $\mathrm{Pa}$ - Palaearctic; $\mathrm{Na}$ - Nearctic; At - Afrotropical; $\mathrm{Nt} \mathrm{-} \mathrm{Neo-}$ tropical; Im - Indomalayan; Au - Australasian

2. táblázat A vágómadár-alakúak főbb csoportjainak rekonstruált ősi elterjedési területe. A táblázat a főbb alcsaládok nevét, az ezekbe sorolt génuszokat, az alcsaládok molekuláris datálás által becsült korát, a legvalószínűbb ősi elterjedési területet, illetve ennek a valószínűségét mutatja. A földrajzi elterjedések rövidítése: $\mathrm{Pa}$ - Palearktisz; $\mathrm{Na}$ - Nearktisz; At - Afrotropisz; Nt - Neotropisz; Im - Indomaláj; Au - Ausztrálázsiai 
Table/táblázat $3 a$

\begin{tabular}{|c|c|c|c|c|c|c|}
\hline Species & Distribution & $\begin{array}{c}\text { Ancestor's age } \\
\text { (Mya; 95\% HPD } \\
\text { interval) }\end{array}$ & $\begin{array}{c}\text { Ancestor's } \\
\text { posterior } \\
\text { node support }\end{array}$ & $\begin{array}{l}\text { Prob. of } \\
\text { ancestor } \\
\text { being non- } \\
\text { migratory }\end{array}$ & $\begin{array}{l}\text { Ancestor's } \\
\text { distribution }\end{array}$ & Prob. \\
\hline Accipiter gularis & $\mathrm{Pa}$ & $0 ; 0.5$ & 0.95 & 0.98 & Palm & 0.56 \\
\hline Accipiter nisus & PaAtlm & $2.4 ; 5.2$ & 0.42 & 0.84 & NtPaAtlm & 0.21 \\
\hline Accipiter soloensis & Palm & $6.3 ; 13.3$ & 0.92 & 0.96 & $\operatorname{ImAu}$ & 0.18 \\
\hline Accipiter striatus & $\mathrm{NaNt}$ & $1.3 ; 3.3$ & 0.53 & 0.84 & NaNtAt & 0.51 \\
\hline Aegypius monachus & PaAt & $2 ; 4$ & 1.00 & 0.98 & At & 0.46 \\
\hline Aquila chrysaetos & $\mathrm{NaPaAt}$ & $3.6 ; 6.2$ & 1.00 & 0.99 & At & 0.91 \\
\hline Aquila heliaca & $\mathrm{Pa}$ & $0.5 ; 1.6$ & 0.94 & 0.99 & $\mathrm{~Pa}$ & 1.00 \\
\hline Aquila nipalensis & $\mathrm{Pa}$ & $1.6 ; 3.5$ & 1.00 & 0.97 & $\mathrm{~Pa}$ & 0.99 \\
\hline Hieraaetus wahlbergi & At & $3.8 ; 6.6$ & 1.00 & 0.59 & At & 1.00 \\
\hline Butastur indicus & Palm & $2.1 ; 5.1$ & 0.83 & 0.56 & Im & 0.32 \\
\hline Butastur rufipennis & At & $2.9 ; 6.4$ & 1.00 & 0.57 & At & 0.29 \\
\hline Buteogallus anthracinus & $\mathrm{NaNt}$ & $0 ; 0.1$ & 1.00 & 1.00 & $\mathrm{Nt}$ & 0.95 \\
\hline Buteogallus meridionalis & $\mathrm{Nt}$ & $2.7 ; 4.5$ & 1.00 & 1.00 & $\mathrm{Nt}$ & 1.00 \\
\hline Buteo lineatus & $\mathrm{Na}$ & $1.1 ; 2.1$ & 1.00 & 0.79 & $\mathrm{NaNt}$ & 0.38 \\
\hline Buteo nitidus & $\mathrm{NaNt}$ & $3 ; 4.8$ & 0.32 & 0.66 & $\mathrm{Na}$ & 0.71 \\
\hline Buteo platypterus & $\mathrm{NaNt}$ & $2.8 ; 4.5$ & 0.99 & 0.70 & $\mathrm{Na}$ & 0.72 \\
\hline Buteo polyosoma & $\mathrm{Nt}$ & $0.4 ; 1.1$ & 1.00 & 0.99 & $\mathrm{Nt}$ & 1.00 \\
\hline Buteo swainsoni & $\mathrm{Na}$ & $0.2 ; 0.4$ & 1.00 & 0.99 & $\mathrm{Nt}$ & 0.44 \\
\hline Circaetus fasciolatus & At & $1.5 ; 3.9$ & 1.00 & 0.91 & At & 1.00 \\
\hline Circaetus gallicus & PaAtlm & $2.8 ; 6.1$ & 1.00 & 0.78 & At & 0.78 \\
\hline Circaetus pectoralis & At & $4.7 ; 8.8$ & 1.00 & 0.79 & At & 0.99 \\
\hline Elanoides forficatus & $\mathrm{NaNt}$ & $15.5 ; 25.1$ & 0.53 & 0.84 & $\mathrm{NtPa}$ & 0.22 \\
\hline Gypohierax angolensis & At & $18 ; 27.8$ & 0.43 & 0.88 & At & 0.90 \\
\hline Gyps coprotheres & At & $0.3 ; 0.8$ & 0.35 & 1.00 & At & 0.40 \\
\hline Gyps fulvus & PaAt & $0.3 ; 0.9$ & 0.66 & 1.00 & At & 0.96 \\
\hline Haliaeetus leucogaster & ImAu & $0 ; 0.3$ & 1.00 & 0.89 & $\mathrm{Au}$ & 0.87 \\
\hline Haliaeetus vocifer & At & $0.7 ; 1.9$ & 1.00 & 0.91 & At & 1.00 \\
\hline Haliastur sphenurus & $\mathrm{Au}$ & $2.3 ; 4.8$ & 1.00 & 0.70 & $\mathrm{Au}$ & 0.37 \\
\hline Hieraaetus ayresii & At & $2.4 ; 4.7$ & 1.00 & 0.51 & At & 0.88 \\
\hline Hieraaetus pennatus & PaAt & $0.7 ; 1.7$ & 1.00 & 0.53 & PaAtAu & 0.28 \\
\hline Macheiramphus alcinus & At & $13.6 ; 24.4$ & 0.99 & 1.00 & NtAt & 0.20 \\
\hline Neophron percnopterus & PaAtlm & $14.4 ; 24.7$ & 1.00 & 0.87 & At & 0.42 \\
\hline Pandion haliaetus & NaNtPaAtImAu & $37 ; 49.5$ & 1.00 & 0.91 & At & 0.37 \\
\hline Parabuteo unicinctus & $\mathrm{NaNt}$ & $4.5 ; 7.5$ & 1.00 & 0.98 & $\mathrm{Nt}$ & 0.95 \\
\hline Polyboroides typus & At & $18.5 ; 29$ & 0.95 & 0.91 & At & 0.99 \\
\hline Rostrhamus sociabilis & $\mathrm{NaNt}$ & $7.5 ; 12$ & 0.96 & 0.99 & $\mathrm{Nt}$ & 0,96 \\
\hline
\end{tabular}


Table/táblázat $3 b$

\begin{tabular}{|c|l|c|c|c|c|c|}
\hline $\begin{array}{c}\text { Node } \\
\text { number }\end{array}$ & Distribution & $\begin{array}{c}\text { Ancestor's age } \\
\text { (Mya; 95\% HPD } \\
\text { interval) }\end{array}$ & $\begin{array}{c}\text { Ancestor's } \\
\text { posterior node } \\
\text { support }\end{array}$ & $\begin{array}{c}\text { Prob. of } \\
\text { ancestor } \\
\text { being non- } \\
\text { migratory }\end{array}$ & $\begin{array}{c}\text { Ancestor's } \\
\text { distribution }\end{array}$ & Prob. \\
\hline 185 & NaNtPaAtImAu & $14.4 ; 29.4$ & 1.00 & 0.77 & $\mathrm{Nt}$ & 0.15 \\
\hline 217 & $\mathrm{Nt}$ & $11.7 ; 18.2$ & 1.00 & 0.63 & $\mathrm{Nt}$ & 0.71 \\
\hline 251 & $\mathrm{NaPa}$ & $7.1 ; 11.9$ & 1.00 & 0.93 & $\mathrm{Im}$ & 0.10 \\
\hline 255 & $\mathrm{PaAtImAu}$ & $5.3 ; 9.3$ & 1.00 & 0.69 & $\mathrm{Au}$ & 0.38 \\
\hline 261 & $\mathrm{NaNt}$ & $9.5 ; 14.5$ & 0.90 & 0.99 & $\mathrm{Nt}$ & 0.93 \\
\hline 344 & $\mathrm{~Pa}$ & $2.1 ; 4.4$ & 0.98 & 1.00 & $\mathrm{~Pa}$ & 0.81 \\
\hline 359 & $\mathrm{~Pa}$ & $15.5 ; 25.1$ & 0.84 & 0.53 & $\mathrm{NtPa}$ & 0.22 \\
\hline
\end{tabular}

Table 3. Possible cases of independent appearance of migration in Accipitriformes. This table lists migratory species (a) or nodes that were inferred to be migratory with a probability $>0.8$ (b) with non-migratory ancestors. The probability that the ancestor was non-migratory, as inferred from ancestral character estimation, is shown along each possible case. Note that only those cases are listed where this probability is $>0.5$, i.e. the node is more likely to be non-migratory than migratory. The greater this value, the higher is our confidence that migration appeared on this branch. Also shown are the ancestral nodes' posterior support, the $95 \%$ highest posterior density (HPD) interval of the nodes' age, along with the most likely distribution of these nodes and the probability that the node was in this state, as inferred in the ancestral area reconstruction. Geographic distribution is abbreviated as: Pa - Palaearctic; Na - Nearctic; At - Afrotropical; Nt - Neotropical; Im - Indomalayan; Au - Australasian. Node numbers appearing in (b) are shown in Figure 3

3. táblázat $\mathrm{A}$ vágómadár-alakúak törzsfejlődése során a vonulás egymástól függetlenül többször megjelent. Ez a táblázat azokat a vonuló fajokat (a) vagy közös ősöket (b) mutatja, amelyek nagy valószínűséggel vonulók voltak (>0.8 valószínűséggel). Mindegyik esetben fel van tüntetve: (i) a vonuló faj (ős) jelenlegi (becsült) előfordulása, (ii) a közvetlen ősük becsült kora, (iii) a közvetlen ős filogenetikai helyzetének pontossága, (iv) annak a valószínűsége, hogy a közvetlen ős nem-vonuló volt, (v) a közvetlen ős rekonstruált ősi elterjedési területe, illetve (vi) annak a valószínűsége, hogy az ősi elterjedés ténylegesen ebben az állapotban volt. Csak azok az esetek szerepelnek, ahol a közvetlen ős legalább 0.5 valószínűséggel helytülő volt. Minél nagyobb ez az érték, annál bizonyosabb, hogy a vonulás ténylegesen ezen az ágon alakulhatott ki. A földrajzi elterjedések rövidítése: Pa - Palearktisz; Na - Nearktisz; At - Afrotropisz; Nt - Neotropisz; Im - Indomaláj; Au - Ausztrálázsiai. A (b)-ben szereplő számok közös ősöket jelölnek, amelyeknek helyzete a 3. ábrán látható

Figure 3. Bayesian ancestral state reconstruction of migratory behavior in Accipitriformes. Tip labels show migratory behavior in extant species (white: non-migratory; black: partial or complete migrant). Pie charts labelling the nodes show the probability that the given species was migratory (black) or non-migratory (white). A completely black chart indicates that the ancestor was migratory with high posterior probability. The size of the charts is proportional to the posterior support of specific nodes: small charts indicate high uncertainity in phylogenetic reconstruction

3. ábra Vonulási viselkedés rekonstrukciója a vágómadár-alakúak törzsfáján. A fajnevek melletti négyzetek színe az illető fajok vonulási viselkedését jelöli (fehér - helytülö; fekete - részleges vagy teljes vonuló). A közös ősöket jelölő kördiagrammok mutatják annak a valószínűségét, hogy az illető faj vonuló volt (fekete). A kördiagrammok mérete egyenesen arányos az illető csomópontok rekonstrukciójának pontosságával 


\section{Evolution of migration in Accipitri- formes}

Table 3 shows possible cases of independent appearance of migratory behavior in Accipitriformes. Since the presence of migration is quite variable among species, our reconstruction of ancestral states involves conside- rable uncertainty in some nodes. On the other hand, in several cases (e.g. Buteo hawks, Accipiter hawks or Haliaeetus eagles), closely related species are all migratory, with the consequence that the most likely state for the ancestor of these species is being migratory.

Two important patterns can be seen from this list of evolutionary events. First, most of

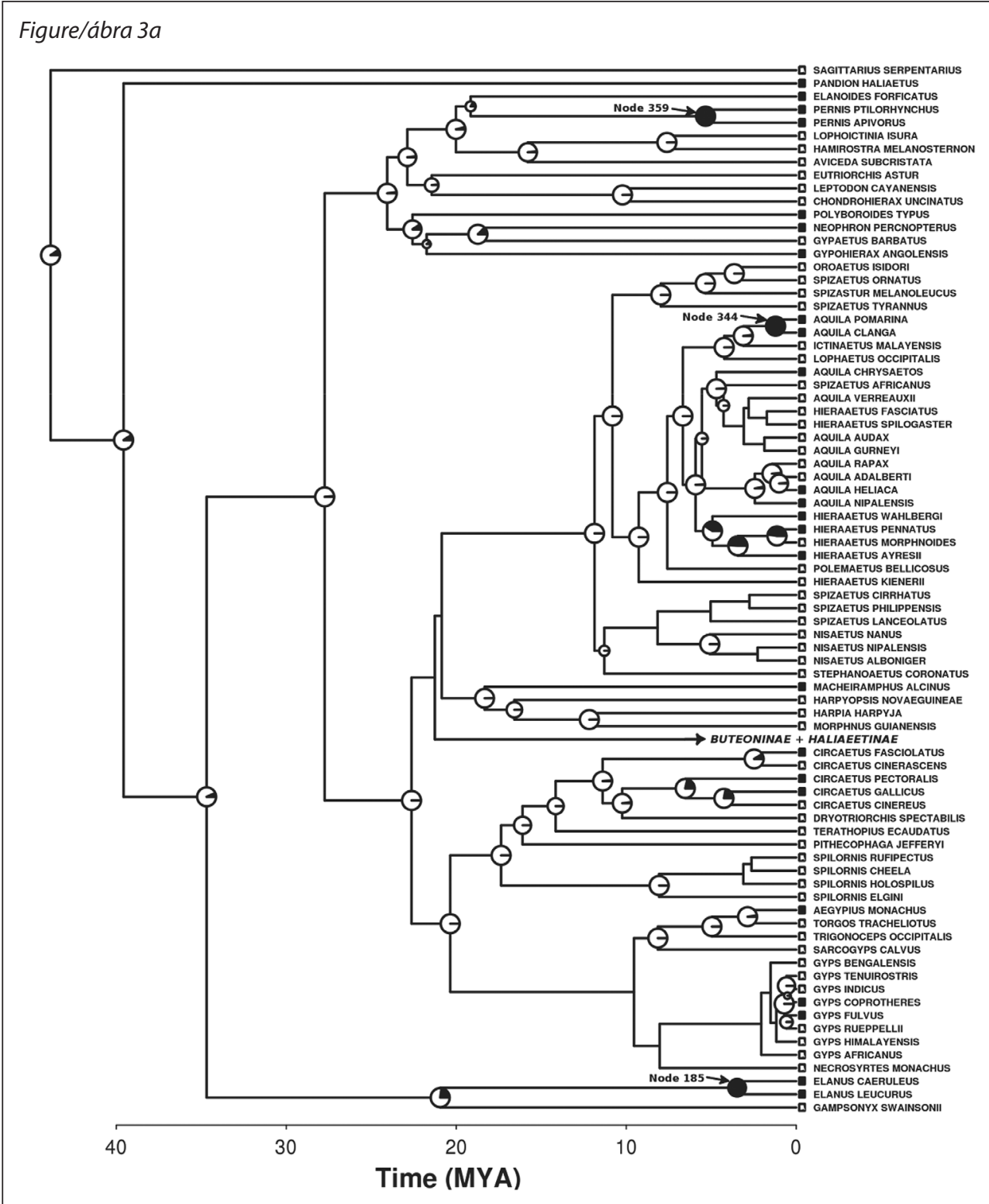




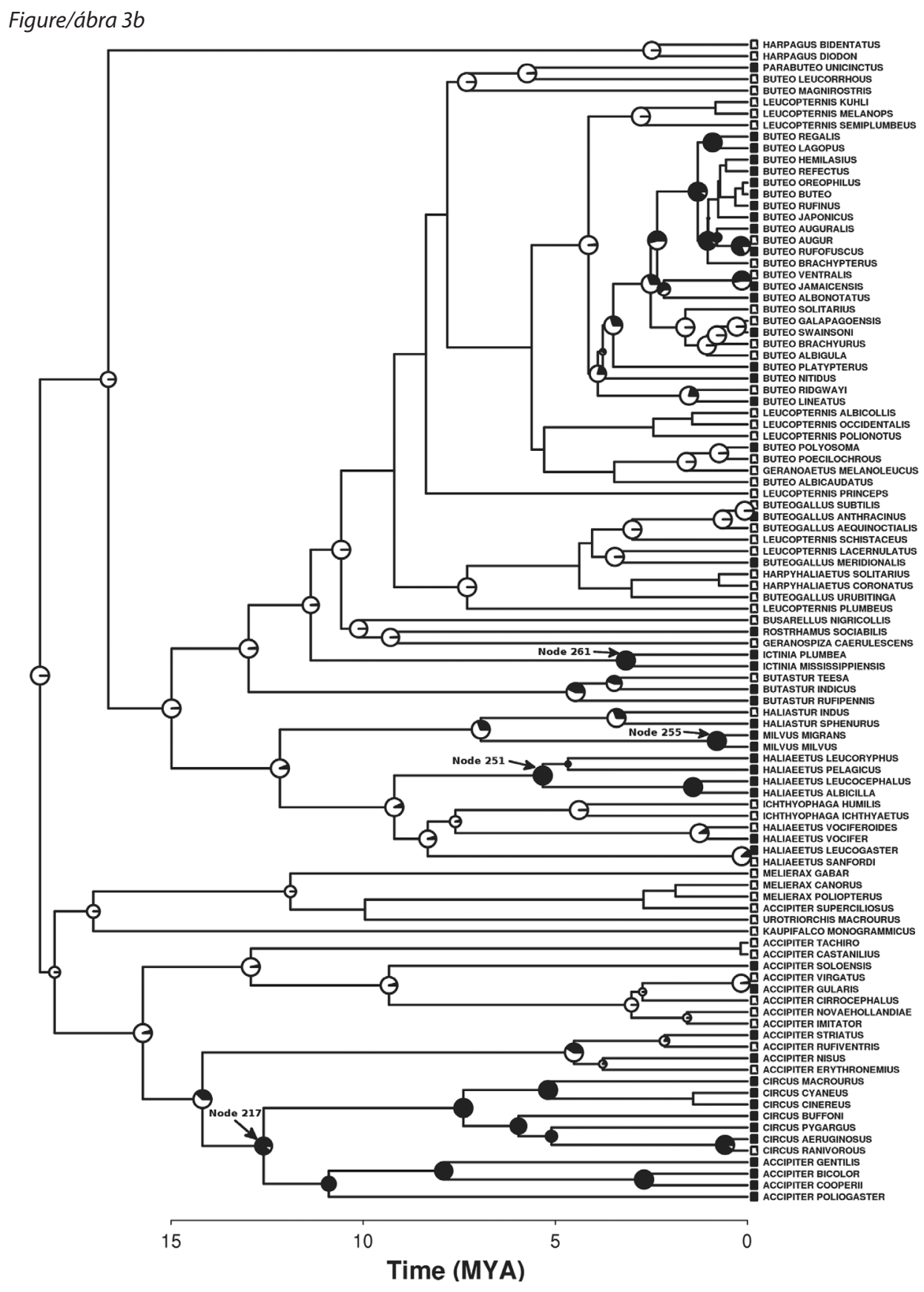


Figure 4. Evolutionary transition rates between levels of migratoriness in birds of prey

4. ábra Vonulási stratégiák közötti evolúciós tranzíciós ráták

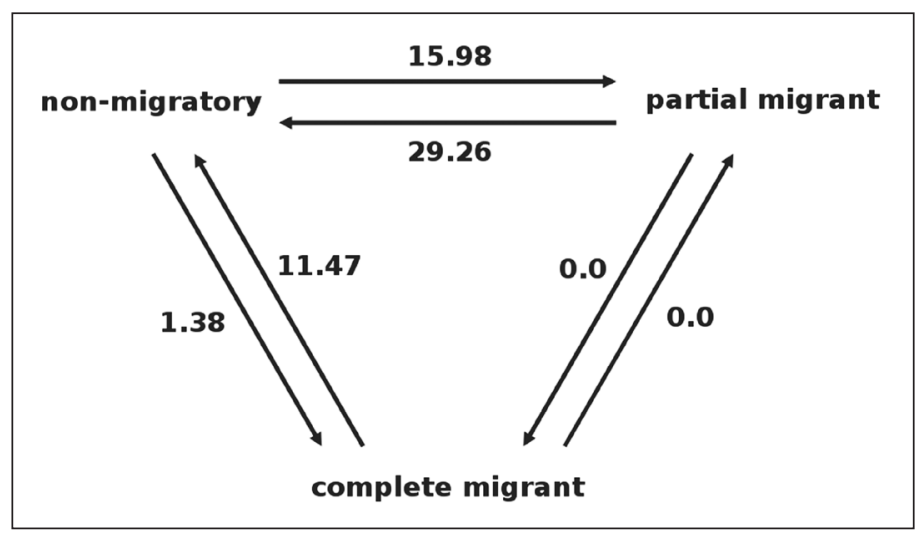

the independent events leading to the appearance of migration involve single species (Table 3a). In these situations, the upper bound for the time of appearance of migration is the age of that particular species (i.e. when it split off from its ancestor). Hence, migration could have appeared in these lineages recently; this possibility is supported by the observation that most of these upper bounds are not older than the beginning of the Pliocene epoch ( $\sim 5.3 \mathrm{Mya})$. On the other hand, nodes that are reconstructed as migratory provide lower estimates for the origin of migration (Table $3 b$ ). The oldest of these nodes is the common ancestor of the Goshawk and the harriers, with an estimated age of 12.9 Mya ( $95 \%$ highest posterior density interval: 16.3-10.1 Mya).

Second, a tropical or partly tropical ancestral area was inferred for the ancestor of most migratory lineages. There are very few exceptions from this pattern. For instance, our results suggest that Aquila heliaca and A. nipalensis (both migratory) evolved within the Palearctic from non-migratory ancestors. Similarly, two migratory Buteo hawks (B. platypterus and B. nitidus) seem to have evolved in the Nearctic from non-migratory ancestors, although in these latter cases posterior support for the phylogenetic reconstruction is quite low $(0.32$ for the ancestor of $B$. nitidus). In sum, our results provide broad support for a tropical origin of migratory species.

\section{Comparative analyzes}

Analysis of the transition rates using BayesTraits Multistate module revealed that both complete and partial migrations evolved from a non-migratory state, but evolutionary transitions between partial and complete migration or vice versa are very low (Figure 4), suggesting that partial migration is not a transitional state between complete migration or lack of migration.

Multivariate analysis of the ecological factors influencing migration suggests that only diet breadth and habitat are associated with migration (Table 4). However, when this multivariate model is simplified by backward elimination of nonsignificant parameters, habitat type does not remain significant. Hence, the only ecological factor associated significantly with migration was winter diet breadth: species with a more generalist winter diet are more likely to be migratory.

Finally, we performed directional tests between migratory behavior on one hand and geographic distribution and diet breadth, respectively, on the other. In the first case, we found that evolutionary transitions to 


\begin{tabular}{|l|c|c|c|c|}
\hline & $\begin{array}{c}\text { Parameter } \\
\text { estimate }\end{array}$ & $\begin{array}{c}\text { lower 95\% } \\
\text { confidence } \\
\text { interval }\end{array}$ & $\begin{array}{c}\text { upper 95\% } \\
\text { confidence } \\
\text { interval }\end{array}$ & P-value \\
\hline Habitat (Forest/Open) & 1.30 & 0.13 & 2.27 & 0.02 \\
\hline Old/New World & 0.78 & -0.75 & 1.75 & 0.16 \\
\hline log(body mass) & -0.06 & -0.51 & 0.33 & 0.78 \\
\hline Diet generalism & 0.44 & 0.21 & 0.75 & $<0.01$ \\
\hline Reliance on warm-blooded prey or carcass & 0.00 & -0.21 & 0.23 & 0.99 \\
\hline Habitat: Old/New World interaction & -1.39 & -3.35 & 0.40 & 0.18 \\
\hline
\end{tabular}

Table 4. Factors affecting the occurrence of migration in diurnal birds of prey ( $\mathrm{N}=151$ species); parameter estimates, their $95 \%$ confidence intervals and P-values from a multivariate mixed effect models controlling for phylogeny

4. táblázat $A$ vonulás előfordulását befolyásoló tényezők vágómadár-alakúaknál ( $N=151$ faj); filogenetikai viszonyokra kontrollált többváltozós kevert lineáris modellből származó becsült értékek, azok 95\%-os konfidenciaintervalluma és a P-értékek

migration occured with a higher rate in lineages with a tropical distribution (9.08 vs. 0.73 in lineages with a non-tropical distribution) (Figure 5a). Furthermore, transitions to a non-tropical distribution are much more likely in migratory (30.01) than in non-migratory lineages $(0.15)$. The tran-

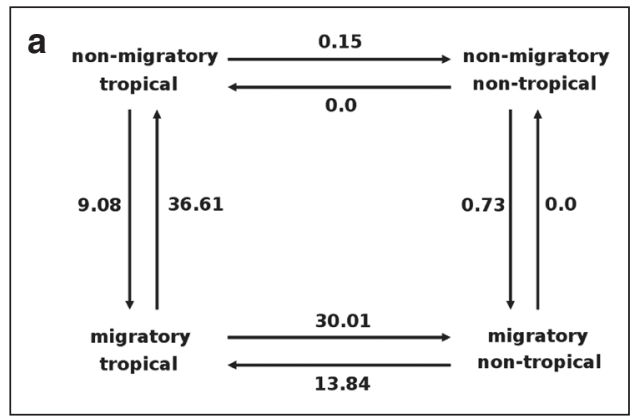

sition rates also revealed that switches in the geographic distribution from a tropical to a non-tropical distribution or vice versa are virtually lacking in non-migratory lineages, whereas they occur at a relatively high rate in migrants (Figure 5a). In the second case, transition rates indicate that migration

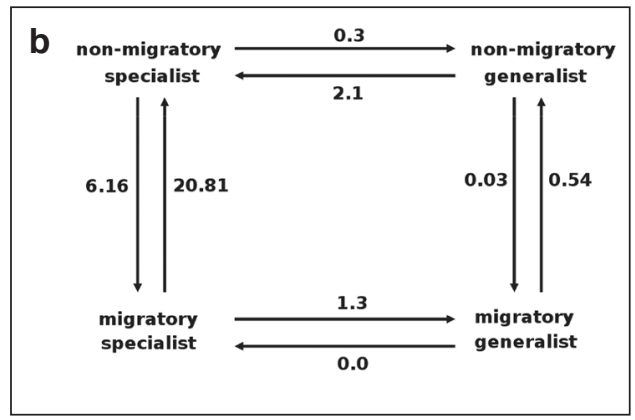

Figure 5. Results from pairwise directional test between migratory behavior (migratory or non-migratory) and (a) geographic distribution: tropical (species not present in the Nearctic or the Palearctic) or non-tropical (species present in the Nearctic or the Palearctic); (b) diet specificity: specialist (consumes $<5$ types of food) or generalist (at least 5 food types consumed). The graph show transition rates among pairs of traits indicating the rate with which these evolutionary changes are inferred to have occurred on the phylogeny

5. ábra A vonulási viselkedés és a földrajzi elterjedés (a) illetve a táplálékspecializáció (b) közötti direkcionális tesztek eredményei. A vonulási viselkedés kódolása: vonuló (részlegesen vagy teljesen) vagy nem vonuló. A földrajzi elterjedés kódolása: trópusi (nem fordul elő sem a Palearktiszban sem a Nearktiszban) vagy nem trópusi (az előző ellentettje). A táplálékspecializáció kódolása: specialista ( $<5$ tápláléktípust fogyaszt) vagy generalista (az előző ellentettje). Az ábra a különböző jellegpárok közötti evolúciós tranzíciós rátákat mutatja 
is more likely to arise in specialist lineages and that a generalist diet is more likely to evolve in migrants than in non-migrants. Hence, it appears that diet breadth evolves as in response to the selective environments imposed by migratoriness, rather than predisposing species for migration.

\section{Discussion}

\section{Phylogeny of Accipitriformes}

The phylogenetic relationships among and within major lineages of Accipitriformes have been extensively studied before (e.g. Wink \& Sauer-Gürth 2004, Helbig et al. 2005, Lerner \& Mindell 2005, Griffths et al. 2007, do Amaral et al. 2009). Here, we combined all available genetic information to produce a multi-gene phylogeny of Accipitriformes with a broad taxonomic sampling, including approximately two-thirds of extant species of accipitrid birds of prey. The phylogenetic hypothesis obtained from this analysis is broadly congruent with previous reports showing that several traditionally established clades are in fact polyphyletic or paraphyletic. For instance, Old World vultures form a polyphyletic clade comprised of: (1) Gypaetinae which is monophyletic with Perninae and includes the Bearded Vulture Gypaetus barbatus and the Egyptian Vulture Neophron percnopterus and (2) Aegypiinae which contains all remaining Old World vultures and is the sister clade of Circaetinae. Accipiter hawks are paraphyletic and should include harriers (Circus spp.), which are closely related to the clade containing goshawks (see also Breman et al. 2013 for a more detailed analysis). In addition, we also observed widespread paraphyly in aquiline eagles and buteonine hawks, as reported previously (Helbig et al. 2005, do Amaral et al. 2009).

On the other hand, we also observed several discrepancies in the higher level relationships of Accipitridae between our reconstructions and those of obtained from previous studies (e.g. Lerner \& Mindell 2005, Griffiths et al. 2007). For instance, we recovered Aquilinae and Harpiinae as sister clades, albeit with relatively low support (posterior probability: 0.45). Harpagus kites were inferred as the sister group of the clade containing Buteoninae and Haliaeetinae with relatively high support (posterior probability: 0.83 ). Lastly, the sister relationship between the clade containing Aquilinae and Harpiinae on one hand and Buteoninae, Haliaeetinae and Accipitrinae on the other was strongly supported (posterior probability: 1).

\section{Historical biogeography and evolution of migration in Accipitriformes}

Our ancestral state reconstruction suggests that migratory behavior in birds of prey evolved multiple times. Most of these appear to be relatively recent events (occurring during the Pliocene or Pleistocene, i.e. $<5$ million years ago). In one case however, migratory behavior appears to be much more ancient. In true hawks (Accipitrinae) migration appears to have evolved approximately 14-12 million years ago, during the middle of the Miocene period. By comparison, do Amaral et al. (2009) reconstructed the origin of migration in one Buteo clade at approximately 5 million years ago, a result that is supportedby our analyses (Figure 3b). More direct estimates based on the age distribution of fossilized individuals (specifically, the lack of juveniles) found at Olduvai Gorge, in Tanzania, suggest that this site was a wintering location of shorebirds belon- 
ging to Charadriidae 1.9-1.74 million years ago, implying that migration was present at this time (Louchart 2008). Hence, our estimate for the origin of migration in accipitrid hawks appears to be one of the oldest dates published so far. Such estimates are important (yet remarkably lacking) if we are to understand the evolution of migration in a constantly changing spatiotemporal context at a global scale (Louchart 2008).

The middle of the Miocene period saw a series of global cooling events (Zachos et al. 2001), which resulted in the expansion of grasslands and contraction of forest habitats, possibly opening new niches for birds of prey. Our analyses suggest that accipitrid hawks appeared shortly before this period, probably in the Afrotropical realm and colonized other parts of the world shortly thereafter. Since most extant species belonging to this lineage are at least partly migratory today, it is likely that their ancestor also performed seasonal migratory movements. Alternatively, migration could have evolved separately in these lineages due to similar selective environments (i.e. as a consequence of convergent evolution rather than shared phylogenetic background). Since migration is a phylogenetically labile trait that can evolve very quickly (see e.g. Zink 2011), independent evolution in multiple lineages experiencing similar selective environments is a plausible scenario for the occurrence of migratory behavior in clusters of closely related species. However, this explanation is clearly less parsimonious in explaining the evolution of migration in true hawks, since this group contains both temperate-tropical and intra-tropical migrants on different continents, which would imply simultaneous, independent selection for migration in a wide variety of different environments on different parts of the world.
Joint reconstruction of ancestral distribution and migratory behavior suggests that in raptors, migration appeared mostly in species with a southern origin. This is further strengthened by our directional analyses, which suggest that migration is more likely to evolve in tropical species and that migratory raptors are more likely to switch to a non-tropical breeding range, hence suggesting that migratory behavior and range expansions are evolving in parallel. Interestingly, we also found that the transition rate from a tropical to non-tropical distribution (and vice versa) is very low in non-migratory raptors, but not in migrants, suggesting that migration greatly enhanced range expansions in this group of birds.

The southern origin of migratory raptors is in line with previous studies obtaining similar results in a variety of taxonomic groups (Joseph et al. 1999, Outlaw et al. 2003, Milá et al. 2006). We have to emphasize, however, that this result helps little in understanding the evolution of migration in birds of prey. As we have shown, all major lineages within Accipitridae trace back their origin to one of the southern biogeographic realms. Hence, both migratory and non-migratory species currently inhabiting the temperate zone descend from the tropics. Our analyses do suggest, however, that migration is more likely to emerge in the tropics than in the temperate zone, and that migratory birds are more likely to disperse and switch from a tropical distribution to a non-tropical one. Hence, the relationship between colonization of the temperate zone and the evolution of migration could be the reverse of what traditionally is assumed, i.e. migratory birds (intratropical migrants) more likely to colonize novel habitats and expand to North. This hypothesis could be tested in the future by investigating the ecological and behavioral traits pro- 
moting the colonization of temperate habitats in a broader sample of birds.

Since all birds of prey are of tropical ancestry, their ancestors must have undergone range expansions to the temperate region. Yet, not all of these species became migratory. We found that winter diet specialization predicts the occurrence of migration in accipitrid birds of prey, with migratory species relying on more variable diets. The ability to feed on a wide source of food types could greatly enhance the probability that a species survives the winter in the temperate zone where food availability is much lower during the winter (Newton 2008). Hence, this could at least partly explain interspecific differences in migratoriness. Interestingly, we found no association between migration and reliance on warm-blooded prey or carcass, suggesting that these food sources alone might not be enough to sustain most species in the temperate zone during winter. For instance, two of the four vulture species that occur in Europe (the Griffon Vulture Gyps fulvus, and the Egyptian Vulture) are migratory, despite the fact that their major food source - carcass - is most likely available year-round. However, these food sources might also show sea-

\section{References}

Alerstam, T. 1993. Bird migration. - Cambridge University Press, pp. 420

do Amaral, F. R., Sheldon, F. H., Gamauf, A., Haring, E., Riesing, M., Silveira, L. F. \& Wajntal, A. 2009. Patterns and processes of diversification in a widespread and ecologically diverse avian group, the buteonine hawks (Aves, Accipitridae). - Molecular Phylogenetics and Evolution 53: 703-715. DOI: 10.1016/j.ympev.2009.07.020

Bell, C. P. 2000. Process in the evolution of bird migration and pattern in avian ecogeography. - Journal of Avian Biology 31: 258-265. DOI: 10.1034/j.160 0048X.2000.310218.x

Bell, C. P. 2005. The origin and development of bird migration: comments on Rappole and Jones, and an alternative evolutionary model. - Ardea 93: 115-123. sonal fluctuations (e.g. Kendall et al. 2012). Alternatively, other factors, such as selection for early breeding or extended breeding season could generate differences in migratoriness between populations or species (e.g. Tökölyi \& Barta 2011, Camacho 2013). Further work is required to clarify ecological determinants of migration in birds of prey.

\section{Acknowledgements}

We would like to express our gratitude to the two anonymous referees for their useful comments on our manuscript. J. N. was supported by a scholarship from the University of Debrecen's Talent Development Program (DETEP). J. T. was supported by the TÁMOP 4.2.2.C-11/1/KONV-2012-0010 project; the project is co-financed by the European Social Fund and the European Regional Development Fund. Computations were partly run on Hungarian National Infrastructure Institute supercomputers (http:// niif.hu). We are grateful to József Büki, head of András Keve Library for Ornithology and Nature Conservation for his help in accessing literature in an early part of this study.

Bell, C. P. 2011. Resource buffering and the evolution of bird migration. - Evolutionary Ecology 25: 91106. DOI: $10.1007 /$ s10682-010-9383-4

Berthold, P. 2001. Bird migration: a general survey. Oxford University Press, pp. 272

Boyle, W. A. \& Conway, C. J. 2007. Why migrate? A test of the evolutionary precursor hypothesis. - The American Naturalist 169: 344-359. DOI: 10.1086/511335

Boyle, W. A., Conway, C. J. \& Bronstein, J. L. 2011. Why do some, but not all, tropical birds migrate? A comparative study of diet breadth and fruit preference. - Evolutionary Ecology 25: 219-236. DOI: $10.1007 / \mathrm{s} 10682-010-9403-4$

Breman, F. C., Jordaens, K., Sonet, G., Nagy, Z. T., Van Houdt, J. \& Louette, M. 2013. DNA barco- 
ding and evolutionary relationships in Accipiter Brisson, 1760 (Aves, Falconiformes: Accipitridae) with a focus on African and Eurasian representatives. - Journal of Ornithology 154: 265-287. DOI: 10.1007/s10336-012-0892-5

Brown, J. W., Rest, J. S., García-Moreno, J., Sorenson, M. D. \& Mindell, D. P. 2008. Strong mitochondrial DNA support for a Cretaceous origin of modern avian lineages. - BMC Biology 6: 6. DOI: 10.1186/1741-7007-6-6

Bruderer, B. \& Salewski, V. 2008. Evolution of bird migration in a biogeographical context. - Journal of Biogeography 35: 1951-1959. DOI: 10.1111/j.1365-2699.2008.01992.x

Camacho, C. 2013. Tropical phenology in temperate regions: extended breeding season in a long-distance migrant. - The Condor 115: 830-837. DOI: 10.1525/cond.2013.120192

Castresana, J. 2000. Selection of conserved blocks from multiple alignments for their use in phylogenetic analysis. - Molecular Biology and Evolution 17: $540-552$.

Charif, D. \& Lobry, J. R. 2007. SeqinR 1.0-2: A contributed package to the $\mathrm{R}$ project for statistical computing devoted to biological sequences retrieval and analysis. - In: Bastolla, U., Porto, M., Roman, H. E. \& Vendruscolo, M. (eds.) Structural approaches to sequence evolution. - Springer, Berlin, pp. 207-232.

Cox, G. W. 1985. The evolution of avian migration systems between temperate and tropical regions of the New World. - The American Naturalist 126: 451474.

Darriba, D., Taboada, D. L., Doallo, R. \& Posada, D. 2012. jModelTest 2: more models, new heuristics and parallel computing. - Nature Methods 9: 772. DOI: $10.1038 /$ nmeth.2109

Drummond, A. J., Ho, S. Y., Phillips, M. J. \& Rambaut, A. 2006. Relaxed phylogenetics and dating with confidence. - PLoS Biology 4: e88. DOI: 10.1371/ journal.pbio.0040088

Drummond, A. \& Rambaut, A. 2007. BEAST: bayesian evolutionary analysis by sampling trees. - BMC Evolutionary Biology 7: 214. DOI: 10.1186/14712148-7-214

Dunning, J. B. 2008. CRC handbook of avian body masses. - CRC Press, Boca Raton

Ericson, P. G. P., Anderson, C. L., Britton, T., Elzanowski, A., Johansson, U. S., Källersjö, M., Ohlson, J. I., Parsons, T. J., Zuccon, D. \& Mayr. G. 2006. Diversification of Neoaves: integration of molecular sequence data and fossils. - Biology Letters 2: 543547. DOI: 10.1098/rsbl.2006.0523

Ferguson-Lees, J. \& Christie, D. A. 2001. Raptors of the World. - Houghton Mifflin Company, Boston
Global Raptor Information Network. 2013. Species accounts. - Downloaded from http://www.globalraptors.org.

Griffiths, C. S., Barrowclough, G. F., Groth, J. G. \& Mertz. L. A. 2007. Phylogeny, diversity, and classification of the Accipitridae based on DNA sequences of the RAG-1 exon. - Journal of Avian Biology 38: 587-602. DOI: 10.1111/j.2007.09088857.03971.x

Guindon, S. \& Gascuel, O. 2003. A simple, fast, and accurate algorithm to estimate large phylogenies by maximum likelihood. - Systematic Biology 52 : 696-704. DOI: 10.1080/10635150390235520

Gwinner, E. 1990. Bird migration: physiology and ecophysiology. - Springer-Verlag, Berlin, pp. 435

Hackett, S. J., Kimball, R. T., Reddy, S., Bowie, R. C. K., Braun, E. L., Braun, M. J., Chojnowski, J. L., Cox, W. A., Han, K., Harshman, J., Huddleston, C. J., Marks, B. D., Miglia, K. J., Moore, W. S., Sheldon, F. H., Steadman, D. W., Witt, C. C. \& Yuri, T. 2008. A phylogenomic study of birds reveals their evolutionary history. - Science 320: 1763-1768. DOI: $10.1126 /$ science. 1157704

Hadfield, J. D. \& Nakagawa, S. 2010. General quantitative genetic methods for comparative biology: phylogenies, taxonomies, and multi-trait models for continuous and categorical characters. - Journal of Evolutionary Biology 23: 494-508. DOI: 10.1111/j.1420-9101.2009.01915.x

Harrison, C. J. O. \& Walker, C. A. 1976. Birds of the British upper Eocene. - Zoological Journal of the Linnean Society 59: 323-351. DOI: 10.1111/ j.1096-3642.1976.tb01017.x

Helbig, A. J., Kocum, A., Seibold, I. \& Braun, M. J. 2005. A multi-gene phylogeny of aquiline eagles (Aves: Accipitriformes) reveals extensive paraphyly at the genus level. - Molecular Phylogenetics and Evolution 35: 147-164. DOI: 10.1016/j. ympev.2004.10.003

Jetz, W., Thomas, G. H., Joy, J. B., Hartmann, K. \& Mooers, A. O. 2012. The global diversity of birds in space and time. - Nature 491: 444-448. DOI: 10.1038/nature11631

Joseph, L., Lessa, E. P. \& Christidis, L. 1999. Phylogeny and biogeography in the evolution of migration: shorebirds of the Charadrius complex. - Journal of Biogeography 26: 329-342. DOI: 10.1046/j.13652699.1999.00269.x

Katoh, K., Kuma, K., Toh, H. \& Miyata, T. 2005. MAFFT Version 5: improvement in accuracy of multiple sequence alignment. - Nucleic Acids Research 33: 511-518. DOI: 10.1093/nar/gki198

Kendall, C., Virani, M. Z., Kirui, P., Thomsett, S. \& Githiru, M. 2012. Mechanisms of coexistence in vultures: understanding the patterns of vulture 
abundance at carcasses in Masai Mara National Reserve, Kenya. - The Condor 114: 523-531.

Kondo, B. \& Omland, K. E. 2007. Ancestral state reconstruction ofmigration: multistate analysis reveals rapid changes in New World orioles (Icterus spp.). - The Auk 124: 410-419. DOI: 10.1642/0004-8038(2007)124[410:ASROMM]2.0.CO;2

Landis, M. J., Matzke, N. J., Moore, B. R. \& Huelsenbeck, J. P. 2013. Bayesian analysis of biogeography when the number of areas is large. - Systematic Biology 62: 789-804. DOI: 10.1093/sysbio/syt040

Lerner, H. R. L. \& Mindell, D. P. 2005. Phylogeny of eagles, old world vultures, and other Accipitridae based on nuclear and mitochondrial DNA. - Molecular Phylogenetics and Evolution 37: 327-346. DOI: 10.1016/j.ympev.2005.04.010

Louchart, A. 2008. Emergence of long distance bird migrations: a new model integrating global climate changes. - Naturwissenschaften 95: 1109-1119. DOI: $10.1007 / \mathrm{s} 00114-008-0435-3$

Matzke, N. J. 2013. Probabilistic historical biogeography: new models for founder-event speciation, imperfect detection, and fossils allow improved accuracy and model-testing. - Ph.D. thesis, Department Integrative Biology and Designated Emphasis in Computational and Genomic Biology, University of California, Berkeley. Available at http://phylo.wikidot.com/local-files/biogeobears/Matzke PhD_FINAL_v5_w_refs.pdf.

Milá, B., Smith, T. B. \& Wayne, R. K. 2006. Postglacial population expansion drives the evolution of long-distance migration in a songbird. - Evolution 60: 2403-2409. DOI: 10.1111/j.0014-3820.2006. tb01875.x

Newton, I. 2008. The migration ecology of birds. - Academic Press, London, pp. 976

Outlaw, D. C., Voelker, G., Milá, B. \& Girman, D. J. 2003. Evolution of long-distance migration in and historical biogeography of Catharus thrushes: a molecular phylogenetic approache. - The Auk 120: 299-310. DOI: $\quad$ 10.1642/00048038(2003)120[0299:EOLMIA]2.0.CO;2

Padian, K. \& Chiappe, L. M. 1998. The origin and early evolution of birds. - Biological Reviews 73: 1-42. DOI: 10.1111/j.1469-185X.1997.tb00024.x

Pagel, M., Meade, A. \& Barker, D. 2004. Bayesian estimation of ancestral character states on phylogenies. - Systematic Biology 53: 673-684. DOI: 10.1080/10635150490522232

Pagel, M. \& Meade, A. 2006. Bayesian analysis of correlated evolution of discrete characters by reversible-jump Markov Chain Monte Carlo. - The American Naturalist 167: 808-825. DOI: 10.1086/503444

Paradis, E., Claude, J. \& Strimmer, K. 2004. APE: analyses of phylogenetics and evolution in $\mathrm{R}$ language.
- Bioinformatics 20: 289-290. DOI: 10.1093/bioinformatics/btg412

Rappole, J. H. \& Jones, P. 2002. Evolution of Old and New World migration systems. - Ardea 90: 525537.

R Development Core Team. 2012. R: a language and environment for statistical computing. - R Foundation for Statistical Computing, Vienna. Available at http://www. R-project.org.

Ree, R. H., Moore, B. R., Webb, C. O. \& Donoghue, M. J. 2005. A likelihood framework for inferring the evolution of geographic range on phylogenetic trees. - Evolution 59: 2299-2311. DOI: 10.1111/ j.0014-3820.2005.tb00940.x

Ree, R. H. \& Smith, S. A. 2008. Maximum likelihood inference of geographic range evolution by dispersal, local extinction, and cladogenesis. - Systematic Biology 57: 4-14. DOI: 10.1080/10635150701883881

Ronquist, F. 1997. Dispersal-vicariance analysis: a new approach to the quantification of historical biogeography. - Systematic Biology 46: 195-203. DOI: 10.1093/sysbio/46.1.195

Roulin, A. \& Wink, M. 2004. Predator-prey relationships and the evolution of colour polymorphism: a comparative analysis in diurnal raptors. - Biological Journal of the Linnean Society 81: 565-578. DOI: $10.1111 /$ j.1095-8312.2004.00308.x

Stamatakis, A. 2006. RAxML-VI-HPC: maximum likelihood-based phylogenetic analyses with thousands of taxa and mixed models. - Bioinformatics 22: 2688-2690. DOI: 10.1093/bioinformatics/btl446

Stiles, F. G. 1980. Evolutionary implications of habitat relations between permanent and winter resident landbirds in Costa Rica. - In: Keast, A. \& Morton, E. S. (eds.) Migrant Birds in the Neotropics. - Smithsonian Institution Press, Washington D.C., pp. $421-435$.

Tökölyi, J. \& Barta, Z. 2011. Breeding phenology determines evolutionary transitions in migratory behaviour in finches and allies. - Oikos 120: 184 193. DOI: 10.1111/j.1600-0706.2010.18592.x

Wink, M. \& Sauer-Gürth, H. 2004. Phylogenetic relationships in diurnal raptors based on nucleotide sequences of mitochondrial and nuclear marker genes. - In: Motta-Junior, J. C., Bueno, A., Chancellor, R. \& Meyburg, B. U. (eds.) Raptors worldwide. WWGBP, Berlin, pp. 483-498.

Zachos, J., Pagani, M., Sloan, L., Thomas, E. \& Billups, K. 2001. Trends, rhythms, and aberrations in global climate $65 \mathrm{Ma}$ to present. - Science 292: 686-693. DOI: $10.1126 /$ science. 1059412

Zink, R. M. 2011. The evolution of avian migration. - Biological Journal of the Linnean Society 104: 237-250. DOI: 10.1111/j.1095-8312.2011.01752.x 